\title{
RESPONSE OF MEXICAN PETUNIA (RUELLIA BRITTONIANA, L.) TO SALINITY, ORGANIC AND BIO MATERIALS
}

\author{
FARDOUS, M. A. ${ }^{1^{*}}-$ HegAZI, M. A. ${ }^{1}-$ EL-BABLY, S. Z. ${ }^{2}-$ HANA, M. R..$^{2^{*}}$ \\ ${ }^{1}$ Hort. Dept., Fac. Agric., Kafr El-Sheikh Univ., Kafr El-Sheikh, Egypt \\ ${ }^{2}$ Research Institute, Agric. Research Center, Kafr El-Sheikh, Egypt \\ *Corresponding author \\ e-mail: maria_magdy_1@yahoo.com
}

(Received $15^{\text {th }}$ Jan 2020; accepted 22 $2^{\text {nd }}$ May 2020)

\begin{abstract}
Mexican petunia (Ruellia brittoniana), belongs to the of family Acanthaceae. It is native to Mexico but it has escaped cultivation and established in disturbed areas in the south eastern of the United States and can be found invading habitats across the state of Florida which is regarded as the second largest producer of ornamental plants in the United States (Hodges and Haydu, 2002). Water scarcity is the greatest crisis that humanity face in the 21 st century (Singh, 2008). May be water is a renewable resource, but its availability is variable and limited. Nearly every country in the world experiences water shortages during certain periods of the year (Gleick, 1993) and more than 80 countries suffer from serious water deficiency (Jin et al., 2007). To face the deficiency of fresh water for the sustainable development of agriculture, there is increasing awareness among agricultural scientists and planners in the utilization of at least diluted seawater for irrigation of crops (Liu et al., 2003). A series pot of experiments were conducted at Kaferelsheikh University Farm during 2014/2015 and 2015/2016 throughout the year. Seawater was diluted with freshwater to obtain the required percentages of $0,5,10,15,20$ and $30 \%$, in addition; the plants were foliar sprayed with organic or bio materials (humic acid, amino acids and active dry yeast). Each pot $(20 \mathrm{~cm}$ diameter plastic pots) received $200 \mathrm{ml}$ of the suitable diluted seawater every two days and foliar sprayed with organic materials fortnightly throughout the study course (Rahman et al., 2019). The obtained results showed that, plants treated with 5\% seawater in combination with humic acid surpassed control one in all measured traits, namely plant height, shoot fresh and dry weights, as well as improved the root length and weight, increased the flowering number and duration, as well as total chlorophyll. All measured traits gradually declined as the seawater percentage increased in the irrigation water. Seawater at $20 \%$ in combination with amino acids treatment significantly increased plant proline content.
\end{abstract}

Keywords: Mexican petunia, Ruellia brittoniana, L., diluted seawater, biostimulant materials

\section{Introduction}

Ruellia brittoniana, L. (Mexican petunia) (Mexican blue bell) (Katie blue Ruellia) belonging to Acanthaceae family is widely used as an ornamental plant (Richard and Hamilton, 1997). It is a tender evergreen perennial, herbaceous plant spreading upright with moderate density and growth rate and is propagated by seeds or cuttings. It grows in semi shade places and has moderate tolerance to draught. It will be attractive when planted in a container or in perennial borders and can be used as ground covers (Gilman, 1999).

Salinity is one of the major environmental factors limiting plant growth and productivity. In most arid and semiarid areas the competition among agriculture, industry and landscape users for high quality water has promoted the use of alternative water sources for irrigation thus, marginal quality water, somewhat saline, became important in these areas (Chartzoulakis et al., 2002) for the irrigation of ornamental plants (Carter et al., 2005).

Seawater irrigation in agriculture should be developed in the places where there is sufficiently high saline water or seawater. Using saline water to irrigate salt-tolerant crops 
or halophytes is a viable strategy for developing agriculture production as well as, for saving fresh water resources.

In Egypt, the water used for irrigation is often mixed with seawater especially in the area near the coasts. It has a long sea coast, which encourages the utilization of seawater in irrigation and as a mineral fertilizer (Miyamoto et al., 1996; Glenn et al., 1998).

Salt effects involved different results due to the complex interaction among the different morphological, physiological, and biochemical processes (Singh and Chatrath, 2001) that lead to growth inhibition (Sairam and Tyagi, 2004).

Humic acid has a direct effect on plant as a hormone-like compound or indirect effect by increasing nutrients uptake through the chelating effect and retaining membrane permeability of microorganisms, serves as a buffer to neutralize both excessive soil acidity and alkalinity, it also improves both the uptake and retention of vital nutrients, stimulates root development, enhances natural resistance against diseases and stimulates over all plant growth (Atiyeh et al., 2002). Hadi et al. (2011) on Matricaria chamomilla L. obtained the biggest flower head diameter after spraying amino acids solution at the flowering bud stage.

Humic acid improved the vegetative growth and increased carbohydrate formation in plant as all these factors helped in prolongation of the flowering duration (Zadeh and Mirzakhani, 2012).

Amino acids can regulate both plant growth and development through their influence on the bio-synthesis of gibberellins and may also play an important role in plant metabolism and protein assimilation necessary for cell formation (Walter and Nawacke, 1978; Sadak, 2015).

Active dry yeast (Saccharomyces cerevisiae) is a natural source of cytokinins that stimulate cell proliferation and differentiation, control shoot and root morphogenesis, chloroplast maturation and it is a rich source of vitamin B complex, carbohydrates, sugars, enzymes, and minerals (Amer, 2004; Ezz El-Din and Hendawy, 2010).

Active dry yeast was more effective and enhanced all flowering aspects of Dahlia pinnata plants (Manoly and Nasr, 2008).

Ali and Hassan (2013) reported that the longest flowering duration resulted from using humic acid at $150 \mathrm{ppm}$ or proline at $4 \mathrm{ppm}$, respectively with salinity of fresh water (304 ppm).

This search aimed to study the effect of diluted seawater irrigation and the effect of organic materials such as humic acid, amino acids and active dry yeast on growth and chemical composition of Ruellia brittoniana, L. plants.

\section{Materials and methods}

A series of pot experiments were conducted at the Experimental Farm of the Faculty of Agriculture, Kafer El-Sheikh University, Egypt, during 2014/2015 and 2015/2016 seasons to study the effect of diluted seawater irrigation combined with foliar application of biostimulant materials (humic acid, amino acids and active dry yeast) on the growth and chemical constituents of Ruellia brittoniana, L. Physical and chemical analysis of the experimental soil was determined and illustrated in Table 1.

\section{Water salinity}

Sampels of Mediterranean water (Balteem) were diluted with freshwater to obtain the required percentages $(0,10,15,20,25$ and $50 \%$ seawater) and $\mathrm{pH}$ and $\mathrm{EC}$ values of the obtained mixtures were measured and illustrated in Table 2. 
Table 1. Physical and chemical properties of the experimental soil in 2014/2015 and 2015/2016 seasons

\begin{tabular}{|c|c|c|c|c|c|c|c|c|c|c|c|c|c|}
\hline \multirow{2}{*}{ Season } & \multirow{2}{*}{$\begin{array}{c}\text { Sand } \\
\%\end{array}$} & \multirow{2}{*}{$\begin{array}{l}\text { Silt } \\
\%\end{array}$} & \multirow{2}{*}{$\begin{array}{c}\text { Clay } \\
\%\end{array}$} & \multirow{2}{*}{$\mathbf{p H}$} & \multirow{2}{*}{$\underset{\text { dsm }^{-1}}{\text { EC }}$} & \multicolumn{4}{|c|}{ Cations (meq/l) } & \multicolumn{4}{|c|}{ Anions (meq/l) } \\
\hline & & & & & & $\mathbf{C a}^{++}$ & $\mathbf{M g}^{++}$ & $\mathbf{N a}^{+}$ & $\mathbf{K}^{+}$ & $\mathrm{CO}^{3-}$ & $\mathrm{HCO}^{3-}$ & $\mathrm{Cl}^{-}$ & $\mathrm{SO}_{4}$ \\
\hline $1^{\text {st }}$ & 24.12 & 25.67 & 50.21 & 8.59 & 1.42 & 4.08 & 3.63 & 6.50 & 0.32 & - & 3.13 & 7.68 & 3.72 \\
\hline $2^{\text {nd }}$ & 24.34 & 25.85 & 49.81 & 8.2 & 1.40 & 3.52 & 2.89 & 6.85 & 0.45 & - & 2.19 & 7.60 & 5.41 \\
\hline
\end{tabular}

Table 2. $p H$ and EC values of the different diluted seawater mixtures in 2014/2015 and 2015/2016 seasons

\begin{tabular}{c|c|c|c|c}
\hline \multirow{2}{*}{ Seawater \% } & \multicolumn{2}{|c|}{$\mathbf{1}^{\text {st }}$ season } & \multicolumn{2}{c}{$\mathbf{2}^{\text {nd }}$ season } \\
\cline { 2 - 5 } & $\mathbf{p H}$ & $\left.\mathbf{E c} \mathbf{( d s m}^{-\mathbf{1}}\right)$ & $\mathbf{p H}$ & $\left.\mathbf{E c} \mathbf{( d s m}^{\mathbf{- 1}}\right)$ \\
\hline Control (0) & 7.75 & 0.47 & 7.66 & 0.46 \\
$5 \%$ & 7.67 & 7.20 & 7.55 & 6.95 \\
$10 \%$ & 7.68 & 9.36 & 7.57 & 9.23 \\
$15 \%$ & 7.69 & 11.28 & 7.58 & 11.17 \\
$20 \%$ & 7.66 & 12.68 & 7.56 & 12.59 \\
$30 \%$ & 7.64 & 14.97 & 7.54 & 14.87 \\
\hline
\end{tabular}

\section{Plant material and procedure}

Stem cuttings of Ruellia brittoniana, L (average of $7 \mathrm{~cm}$ in length) were planted in September $1^{\text {st }}$ during $2014 / 2015$ and 2015/2016 seasons in pots filled with a clayey soil. After two months the rooted cuttings were transplanted into plastic pots with a diameter of $20 \mathrm{~cm}$ (without drain holes) filled with a clayey soil.

Each pot received $200 \mathrm{ml}$ of the suitable diluted seawater after two months from transplantation every two days and organic or bio stimulants (humic acid, amino acids and active dry yeast) were used as a foliar spray on plant leaves fortnightly throughout the study course. Humic acid was used at $5 \mathrm{ml} / \mathrm{L}$, amino acids $1 \mathrm{~g} / \mathrm{L}$ and active dry yeast at $5 \mathrm{~g} / \mathrm{L}$.

The experimental layout was split plot design. The experiments were conducted twice and the obtained data were subjected to one-way analysis of variance (ANOVA) and Duncan multiple range comparison test $(\mathrm{p}<0.05)$ using them static statistical package.

\section{Determination and measurements}

At the end of the experiments on the 1st September, the following data were recorded in the two experimental seasons:

Survival \%.

Plant height $(\mathrm{cm})$.

Leaf area $\left(\mathrm{cm}^{2}\right)$ calculated by CI-202 Portable Laser Leaf Area Meter (CID Bio-Science Made In USA).

Shoot fresh and dry weights $(\mathrm{g}) /$ plant/season.

Main root length $(\mathrm{cm})$.

Root fresh and dry weight (g)/plant/season.

Flowering duration (days) and number of flowers /plant/season. 
Leaf total green color was measured using a portable chlorophyll meter (Minolta SPAD-502, Japan).

Proline content ( $\mu$ moles/100 g fresh weight) was determined and calculated on a fresh weight basis according to Baters et al. (1973).

Nitrogen (\%) was determined by modified microkjeldahl method as described by A.O.A.C. (1970).

Magnesium and sodium were measured using an atomic absorption spectrophotometer (Jackson, 1973).

Chloride was assayed by titration method indicated by Jackson (1973).

\section{Results}

Effect of diluted seawater, humic acid, amino acids, active dry yeast on Ruellia brittoniana, L. was examined.

\section{Vegetative growth parameters}

Diluted seawater of $30 \%$ was completely lethal for plants. The highest survival percentage was recorded with control treatment (fresh water only) followed by $5 \%$ and $10 \%$ seawater then gradually declined as sea water percentage increased (Fig. 1).

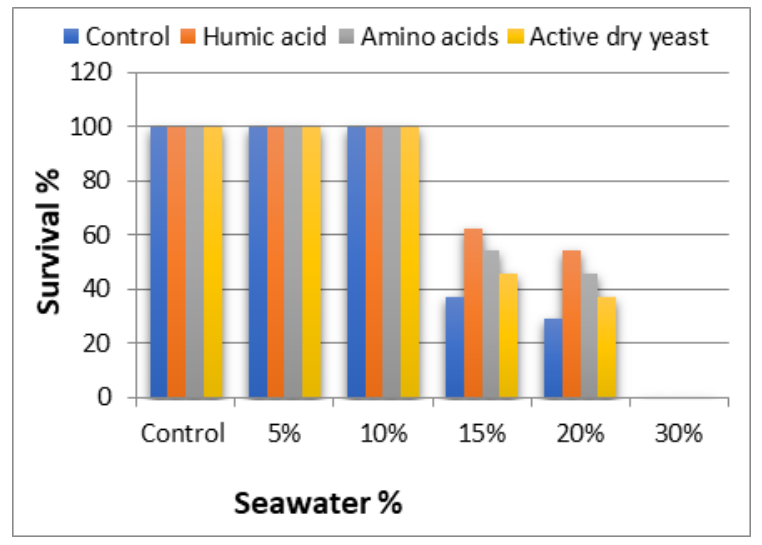

Figure 1. Effect of diluted seawater and biostimulants and their interaction on survival \% of Ruellia brittoniana, L. (mean of both seasons)

Utilizing diluted seawater at 5\% significantly improved all traits such as plant height, shoot fresh and dry weights with significant differences in between whereas control treatment recorded the widest leaves without significant differences. Raising seawater percentage in irrigation water from 10 to $20 \%$ gradually decreased all parameters of vegetative growth (Figs. 2-7).

As for organic or bio stimulants, humic and amino acids significantly augmented the survival\%, plant height, leaf area, shoots fresh and dry weights followed by active dry yeast against the control treatments.

These results confirmed the contribution of organic or bio stimulants with seawater for improving all parameters as survival \%, plant height, leaf area, shoot fresh and dry weights. Seawater at $5 \%$ combined with each of humic acid, followed by amino acids then active dry yeast improved all traits which surpassed control treatment. The 
combination between diluted seawater and organic or bio stimulants resulted in a gradual increment in the parameters comparing to uncombined one.

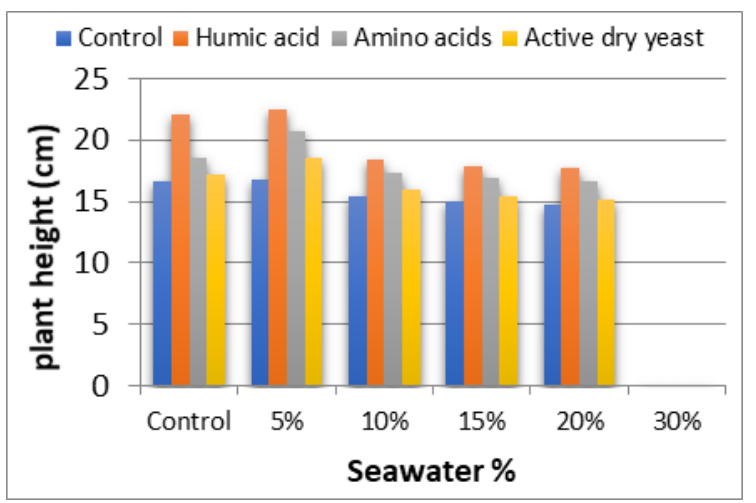

Figure 2. Effect of diluted seawater and biostimulants and their interaction on plant height of Ruellia brittoniana, L. (mean of both seasons)

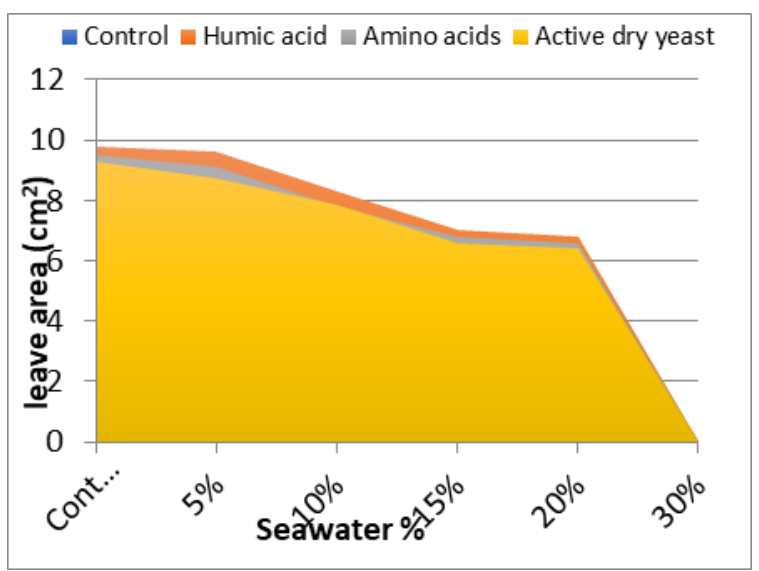

Figure 3. Effect of diluted seawater and biostimulants and their interaction on leaf area of Ruellia brittoniana, $L$.

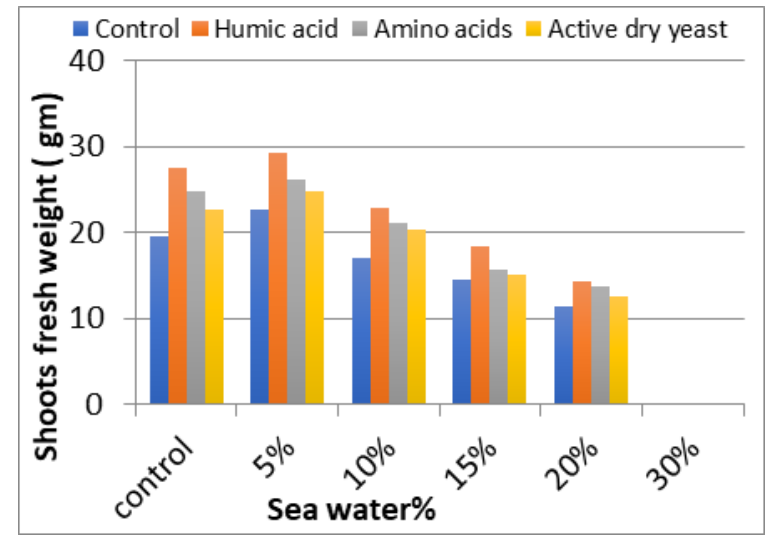

Figure 4. Effect of diluted seawater and biostimulants and their interaction on shoots fresh weight of Ruellia brittoniana, $L$. 


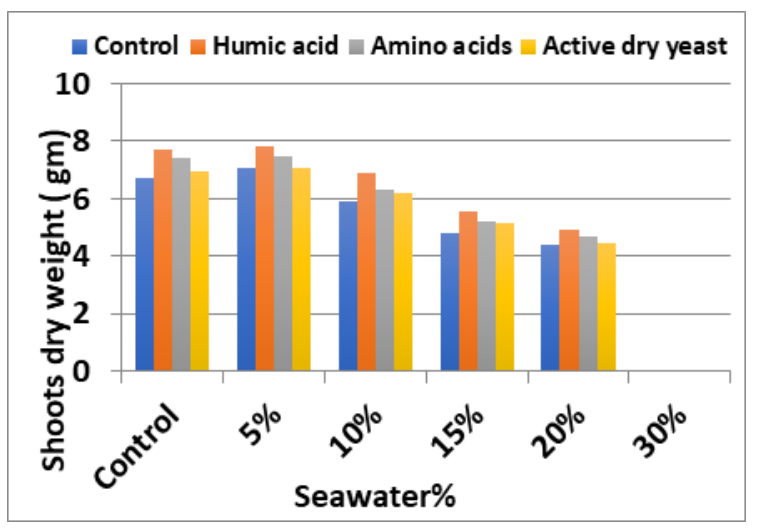

Figure 5. Effect of diluted seawater and biostimulants and their interaction on shoots dry weight of Ruellia brittoniana, $L$.

In general, increasing seawater percent from 10 to $20 \%$ combined with organic or bio stimulants significantly decreased all parameters except for $10 \%$ seawater which gave $(100 \%)$ survival.

\section{Root growth parameters}

Diluted seawater (5\%) treatment significantly enhanced either root length, roots fresh and dry weights which sometimes surpassed or were equivalent to control treatment. Increasing seawater percent in irrigation water from 10 to $20 \%$ gradually decreased all roots parameters (Figs. 6 and 7).

Adding organic or bio stimulants significantly increased root length and root fresh and dry weights.

It was noticed that, humic or amino acids increased root indices followed by active dry yeast and control.

These results are in accordance with those reported by Abourayya et al. (2013) on Manzanillo, who observed an increase in root length due to the reduction in the uptake of salt caused by amino acid proline and potassium humate applications which is probably due to the role of humic acid that affects root processes and increases nutrient uptake.

The interaction between seawater and biostimulant substances showed that, 5 or $0 \%$ seawater with humic acid recorded the highest values of root length, root fresh and dry weights followed by amino acids or active dry yeast with $5 \%$ seawater. Raising seawater percentage from 10 to $20 \%$ with humic acid, amino acid or active dry yeast decreased salinity effects on root length and root fresh and dry weights.

The lowest values were obtained when seawater was used at $20 \%$ without organic or bio stimulants while diluted seawater (20\%) with humic acid, amino acids or active dry yeast increased root length and root fresh and dry weights. Diluted seawater (10 or $15 \%$ ) with humic acid, amino acids or active dry yeast gave higher values of root fresh and dry weights than that resulted from diluted seawater (10 or 15\%) without biostimulant. These results are in agreement with those of El-Mahrouk et al. (2008) on Conocarpus erectus $L$.

\section{Flowering characters}

The longest flowering duration (days) and the highest flowers number/plant resulted from plants irrigated with diluted seawater at 5 or $10 \%$ followed by $15 \%$ diluted 
seawater (Figs. 8 and 9). The shortest flowering duration and the least flower number /plant was obtained when diluted seawater at $20 \%$ was used. These results are in accordance with those of Abdel-Maksoud et al. (2014) on Bellis perennis.

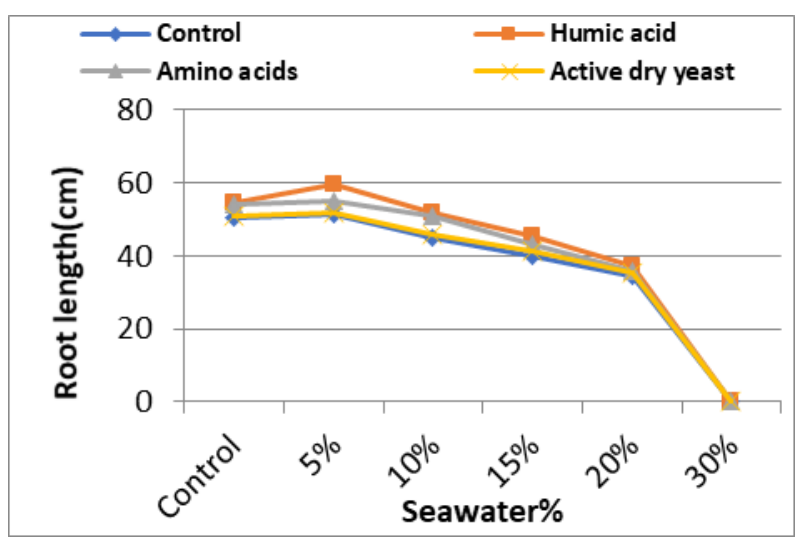

Figure 6. Effect of diluted seawater and biostimulants and their interaction on root length of Ruellia brittoniana, L. during in the first and second seasons

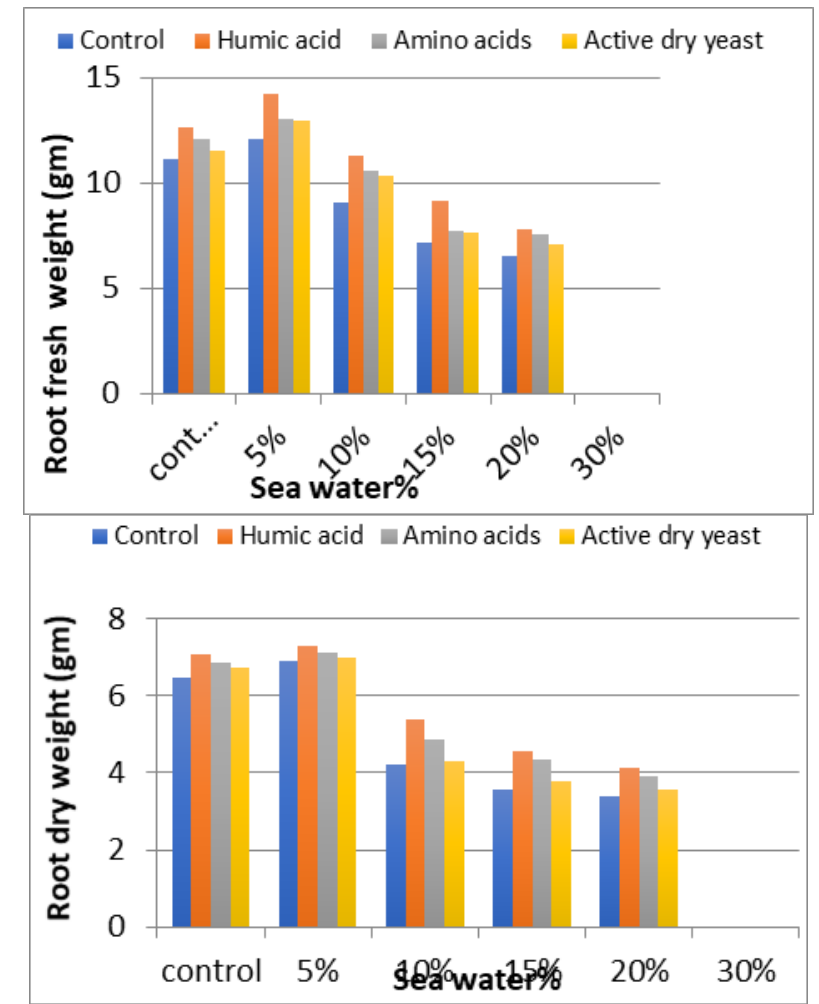

Figure 7. Effect of diluted seawater and biostimulants and their interaction on roots fresh and dry weights of Ruellia brittoniana (mean of both seasons)

As for organic materials, it was noticed that humic or amino acids application resulted in the significantly highest values of flowering duration and flower number/plant followed by active dry yeast compared to control (Hadi et al., 2011) on Matricaria chamomillu, L. 
The combination between diluted seawater irrigation and humic acid, amino acid or active dry yeast beside control resulted in the significantly longest flowering duration and highest flower number/plant compared to diluted seawater irrigation without organic or bio stimulants treatments (Srivastava et al., 2007) on Gladiolus.

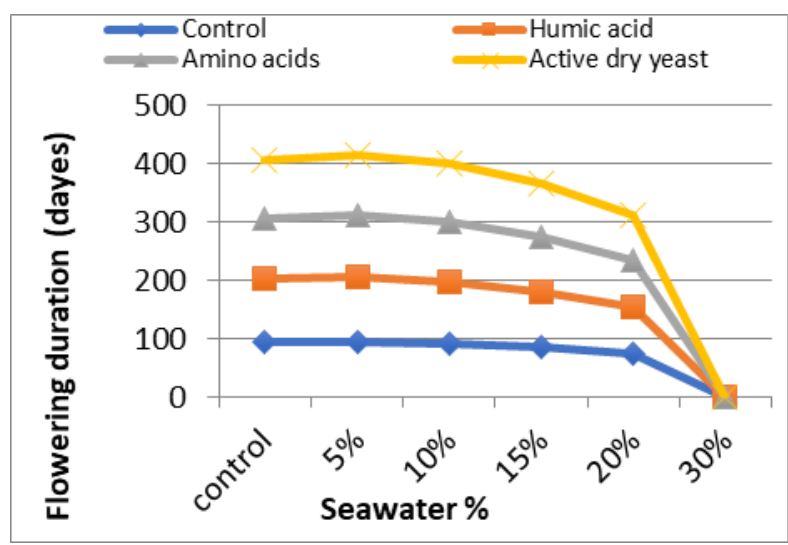

Figure 8. Effect of diluted seawater and biostimulants and their interaction on flowering duration of Ruellia brittoniana (mean of both seasons)

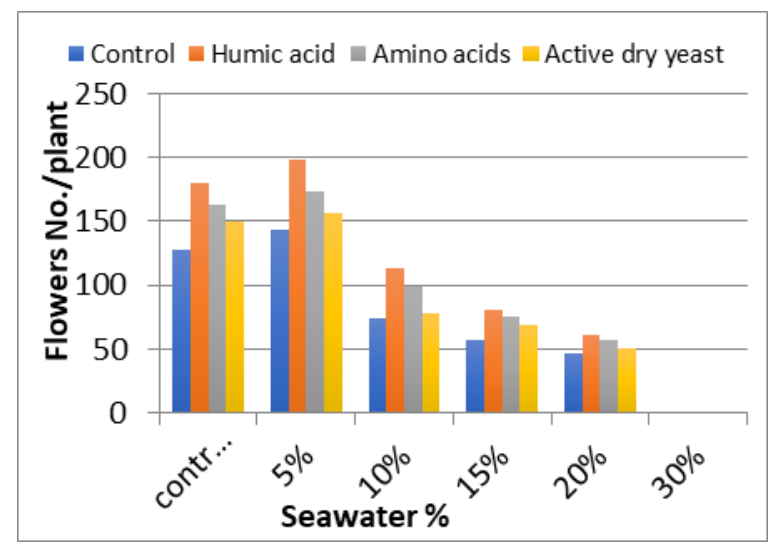

Figure 9. Effect of diluted seawater and biostimulants and their interaction on the number of flowers/plant of Ruellia brittoniana (mean of both seasons)

\section{Biochemical composition}

Data presented in Table 3 cleared that using diluted seawater at 5\% followed by fresh control significantly increased leaves total chlorophyll, but $20 \%$ diluted seawater significantly decreased it. Proline leaves content was significantly augmented with the increase in seawater percent in the irrigation water. Meanwhile, the deficient in leaves proline contents was observed with the lacking of seawater in the irrigation water.

Regarding organic materials, it was found that leaves total chlorophyll was significantly increased by using humic acid followed by amino acids and then active dry yeast compared to control. Amino acid and humic acid significantly increased leaves proline content followed by active dry yeast.

As for the combination between diluted seawater and organic or bio stimulants it was clear that, seawater at $5,10 \%$ or fresh water with humic acid, amino acid or active dry 
yeast significantly increased leaves total chlorophyll contents. In contrast, proline content took an adverse trend as seawater at $20 \%$ only or combined with amino acid resulted the highest values of leaves proline content.

Table 3. Effect of diluted sea water and organic or bio stimulants and their interaction on chlorophyll and proline constituents of Ruellia brittoniana (mean of both seasons)

\begin{tabular}{c|c|c|c|c|c|c|c|c|c|c}
\hline \multirow{2}{*}{$\begin{array}{c}\text { Seawater } \\
\%\end{array}$} & \multicolumn{4}{|c|}{ Chlorophyll (SPAD) } & \multicolumn{4}{c}{ Proline (M.mole/100g fw.) } \\
\cline { 2 - 10 } & $\mathbf{0 . 0}$ & H.A & A.A & Y & Mean & $\mathbf{0 . 0}$ & H.A & A.A & Y & Mean \\
\hline Control & $44.55^{\text {bcd }}$ & $49.32^{\mathrm{ab}}$ & $46.52^{\mathrm{abc}}$ & $45.22^{\mathrm{cde}}$ & $46.40^{\mathrm{b}}$ & $4.5^{\mathrm{f}}$ & $5.9^{\mathrm{f}}$ & $6.7^{\mathrm{c}-\mathrm{f}}$ & $5.0^{\mathrm{f}}$ & $5.5^{\mathrm{d}}$ \\
$5 \%$ & $45.29^{\mathrm{bcd}}$ & $50.30^{\mathrm{a}}$ & $49.28^{\mathrm{ab}}$ & $46.58^{\mathrm{abc}}$ & $47.86^{\mathrm{a}}$ & $5.2^{\mathrm{ef}}$ & $6.8^{\mathrm{c}-\mathrm{f}}$ & $7.5^{\mathrm{c}-\mathrm{f}}$ & $5.8^{\mathrm{ef}}$ & $6.3^{\mathrm{cd}}$ \\
$10 \%$ & $40.75^{\mathrm{d}-\mathrm{g}}$ & $47.10^{\mathrm{ab}}$ & $43.13^{\mathrm{cde}}$ & $41.00^{\mathrm{d}-\mathrm{g}}$ & $43.00^{\mathrm{c}}$ & $6.3^{\mathrm{def}}$ & $8.3^{\mathrm{b}-\mathrm{f}}$ & $8.6^{\mathrm{b}-\mathrm{f}}$ & $7.1^{\mathrm{c}-\mathrm{f}}$ & $7.6^{\mathrm{bc}}$ \\
$15 \%$ & $35.82^{\mathrm{hi}}$ & $42.50^{\mathrm{c}-\mathrm{f}}$ & $39.58^{\mathrm{e} \mathrm{h}}$ & $36.82^{\mathrm{ghi}}$ & $38.68^{\mathrm{d}}$ & $8.7^{\mathrm{b}-\mathrm{f}}$ & $10.9^{\mathrm{a}}$ & $11.5^{\mathrm{abc}}$ & $9.9^{\mathrm{a}-\mathrm{e}}$ & $10.3^{\mathrm{b}}$ \\
$20 \%$ & $32.84^{\mathrm{i}}$ & $37.69^{\mathrm{f}-\mathrm{i}}$ & $35.87^{\mathrm{hi}}$ & $33.99^{\mathrm{i}}$ & $35.10^{\mathrm{e}}$ & $10.9^{\mathrm{a}-\mathrm{d}}$ & $13.5^{\mathrm{a}}$ & $14.5^{\mathrm{a}}$ & $12.5^{\mathrm{abc}}$ & $12.9^{\mathrm{a}}$ \\
$30 \%$ & - & - & - & - & - & - & - & - & - & - \\
Mean & $39.79^{\mathrm{c}}$ & $45.38^{\mathrm{a}}$ & $42.88^{\mathrm{b}}$ & $40.72^{\mathrm{bc}}$ & & $7.1^{\mathrm{c}}$ & $9.1^{\mathrm{ab}}$ & $9.8^{\mathrm{a}}$ & $8.1^{\mathrm{b}}$ & \\
\hline
\end{tabular}

H.A = humic acid, A.A = amino acid, $\mathrm{Y}=$ active dry yeast

Means of each factor designed by the same letters within a column or row are not significantly different at $5 \%$ level according to Duncan's multiple range test

\section{Chemical composition}

\section{Nitrogen and magnesium}

The percent of nitrogen and magnesium significantly declined as seawater percent in the irrigation water increased (Table 4).

Amino acids or humic acid followed by active dry yeast significantly increased both nitrogen and magnesium $\%$. The least values of nitrogen and magnesium $\%$ resulted from control treatment.

As for the interaction between diluted seawater and organic or bio stimulants data presented in Table 4 showed that, amino acids, humic acids or active dry yeast increased leaves $\mathrm{N} \%$ and $\mathrm{Mg} \%$.

Table 4. Effect of diluted sea water and organic or bi stimulants and their interaction on nitrogen and magnesium \% of Ruellia brittoniana (Mean of both seasons)

\begin{tabular}{c|c|c|c|c|c|c|c|c|c|c}
\hline \multirow{2}{*}{$\begin{array}{c}\text { Seawater } \\
\%\end{array}$} & \multicolumn{7}{|c|}{ N\% } & \multicolumn{6}{|c}{ Mg\% } \\
\cline { 2 - 10 } & $\mathbf{0 . 0}$ & H.A & A.A & Y & Mean & 0.0 & H.A & A.A & Y & Mean \\
\hline Control & $2.59^{\mathrm{bcd}}$ & $2.82^{\mathrm{ab}}$ & $2.92^{\mathrm{a}}$ & $2.66^{\mathrm{bc}}$ & $2.75^{\mathrm{a}}$ & $0.62^{\mathrm{a}}$ & $0.66^{\mathrm{a}}$ & $0.68^{\mathrm{a}}$ & $0.63^{\mathrm{a}}$ & $0.65^{\mathrm{a}}$ \\
$5 \%$ & $2.20^{\mathrm{ef}}$ & $2.36^{\mathrm{de}}$ & $2.45^{\mathrm{cde}}$ & $2.24^{\mathrm{e}}$ & $2.31^{\mathrm{b}}$ & $0.52^{\mathrm{b}}$ & $0.54^{\mathrm{b}}$ & $0.55^{\mathrm{b}}$ & $0.53 \mathrm{~b}$ & $0.54^{\mathrm{b}}$ \\
$10 \%$ & $1.59^{\mathrm{hi}}$ & $1.80^{\mathrm{ghh}}$ & $1.97^{\mathrm{fg}}$ & $1.68^{\mathrm{h}}$ & $1.76^{\mathrm{c}}$ & $0.40^{\mathrm{cd}}$ & $0.42^{\mathrm{cd}}$ & $0.43^{\mathrm{c}}$ & $0.41^{\mathrm{cd}}$ & $0.42^{\mathrm{c}}$ \\
$15 \%$ & $1.19^{\mathrm{jk}}$ & $1.31^{\mathrm{jk}}$ & $1.36^{\mathrm{jj}}$ & $1.24^{\mathrm{jk}}$ & $1.28^{\mathrm{d}}$ & $0.35^{\mathrm{de}}$ & $0.37^{\mathrm{cd}}$ & $0.39^{\mathrm{cd}}$ & $0.36^{\mathrm{cde}}$ & $0.37^{\mathrm{d}}$ \\
$20 \%$ & $1.07^{\mathrm{k}}$ & $1.28^{\mathrm{jk}}$ & $1.31^{\mathrm{jk}}$ & $1.19^{\mathrm{jk}}$ & $1.22^{\mathrm{e}}$ & $0.26^{\mathrm{f}}$ & $0.28 \mathrm{f}^{\mathrm{f}}$ & $0.30^{\mathrm{ef}}$ & $0.27^{\mathrm{f}}$ & $0.28^{\mathrm{e}}$ \\
$30 \%$ & - & - & - & - & - & - & - & - & - & - \\
Mean & $1.73 \mathrm{c}$ & $1.91^{\mathrm{b}}$ & $2.00^{\mathrm{a}}$ & $1.80^{\mathrm{bc}}$ & & $0.43^{\mathrm{b}}$ & $0.45^{\mathrm{ab}}$ & $0.47^{\mathrm{a}}$ & $0.44^{\mathrm{b}}$ & \\
\hline
\end{tabular}

H.A = humic acid, A.A = amino acid, $\mathrm{Y}=$ active dry yeast

Means of each factor designed by the same letters within a column or row are not significantly different at $5 \%$ level according to Duncan's multiple range test 
Diluted seawater at $20 \%$ combined with amino acids, humic acid or active dry yeast significantly increased leaves $\mathrm{N} \%$ and $\mathrm{Mg} \%$ while, 10 and $15 \%$ diluted seawater combined with amino acids, humic acid, active dry yeast gave intermediate values.

\section{Sodium and chloride percentage}

Diluted seawater at $20 \%$ progressively increased $\mathrm{Na}$ and $\mathrm{Cl}$ percent in the leaves whereas the percentages were gradually decreased when seawater increased in the irrigation water (Table 5). The lowest $\mathrm{Na}$ and $\mathrm{Cl} \%$ in the leaves were obtained from control treatment.

Table 5. Effect of diluted sea water and organic or biostimulants and their interaction on $\mathrm{Na}$ and $\mathrm{Cl} \%$ of Ruellia brittoniana (mean of both seasons)

\begin{tabular}{c|c|c|c|c|c|c|c|c|c|c}
\hline \multirow{2}{*}{$\begin{array}{c}\text { Seawater } \\
\%\end{array}$} & \multicolumn{9}{|c|}{ Na\% } & \multicolumn{5}{c}{ Cl (mg/g D.W. } \\
\cline { 2 - 10 } & $\mathbf{0 . 0}$ & H.A & A.A & Y & Mean & $\mathbf{0 . 0}$ & H.A & A.A & Y & Mean \\
\hline Control & $0.53^{\mathrm{e}}$ & $0.49^{\mathrm{e}}$ & $0.51^{\mathrm{e}}$ & $0.52^{\mathrm{e}}$ & $0.51^{\mathrm{e}}$ & $4.15^{\mathrm{h}}$ & $3.65^{\mathrm{h}}$ & $3.87^{\mathrm{h}}$ & $4.00^{\mathrm{h}}$ & $3.92^{\mathrm{e}}$ \\
$5 \%$ & $1.01^{\mathrm{cd}}$ & $0.86^{\mathrm{de}}$ & $0.88^{\mathrm{de}}$ & $0.91^{\mathrm{de}}$ & $0.92^{\mathrm{d}}$ & $9.07^{\mathrm{f}}$ & $8.04^{\mathrm{g}}$ & $8.15^{\mathrm{g}}$ & $8.32^{\mathrm{g}}$ & $8.40^{\mathrm{d}}$ \\
$10 \%$ & $1.43^{\mathrm{c}}$ & $1.21^{\mathrm{cd}}$ & $1.24^{\mathrm{cd}}$ & $1.32^{\mathrm{cd}}$ & $1.30^{\mathrm{c}}$ & $11.17^{\mathrm{e}}$ & $10.75^{\mathrm{e}}$ & $10.88^{\mathrm{e}}$ & $10.97^{\mathrm{e}}$ & $10.94^{\mathrm{c}}$ \\
$15 \%$ & $2.53^{\mathrm{b}}$ & $2.11^{\mathrm{b}}$ & $2.20^{\mathrm{bc}}$ & $2.44^{\mathrm{b}}$ & $2.32^{\mathrm{b}}$ & $15.13^{\mathrm{d}}$ & $14.73^{\mathrm{d}}$ & $14.94^{\mathrm{d}}$ & $15.00^{\mathrm{d}}$ & $14.95^{\mathrm{b}}$ \\
$20 \%$ & $3.82^{\mathrm{a}}$ & $3.41^{\mathrm{a}}$ & $3.71^{\mathrm{a}}$ & $3.75^{\mathrm{a}}$ & $3.67^{\mathrm{a}}$ & $20.42^{\mathrm{a}}$ & $18.74^{\mathrm{c}}$ & $19.07^{\mathrm{c}}$ & $19.80^{\mathrm{b}}$ & $19.51^{\mathrm{a}}$ \\
$30 \%$ & - & - & - & - & - & - & - & - & - & - \\
Mean & $1.86^{\mathrm{a}}$ & $1.62^{\mathrm{c}}$ & $1.71^{\mathrm{b}}$ & $1.79^{\mathrm{ab}}$ & -- & $11.99^{\mathrm{a}}$ & $11.18^{\mathrm{c}}$ & $11.38^{\mathrm{bc}}$ & $11.62^{\mathrm{b}}$ & \\
\hline
\end{tabular}

H.A = humic acid, A.A = amino acid, $\mathrm{Y}=$ active dry yeast

Means of each factor noted by the same letters within a column or row are not significantly different at $5 \%$ level according to Duncan's multiple range test

Diluted seawater at 5 and $10 \%$ combined with organic or bio stimulants decreased $\mathrm{Na}$ and $\mathrm{Cl} \%$ in the leaves as compared to control treatment. These values gradually increased with increasing seawater percent. These results agree with those reported by Khaled Fawzy (2011) on Nigella sativa L.

\section{Discussion}

Effect of diluted seawater, humic acid, amino acids, active dry yeast on Ruellia brittoniana, L. was examined.

\section{Vegetative growth}

Diluted seawater of $30 \%$ was completely lethal for plants whereas 5\% significantly improved all traits such as plant height, shoot fresh and dry weights. This may be due to that, salt stress inactivated proteins and enzymes as well as destroyed cell membrane structure and permeability by causing lipid oxidation (Winston, 1990). Also Parida and Das (2005) reported that, salt stress can affect plant survival, biomass and the capacity of plant to collect water and nutrient.

Organic or bio stimulants, humic and amino acids significantly augmented the survival\%, plant height, leaf area, shoots fresh and dry weights followed by active dry yeast against the control treatments. This may be due to that, humic acid has a direct 
effect as a hormone like compound or indirect effect by increasing nutrient uptake through chelate, renewal effects and retaining membrane permeability of microorganisms, improving the physical condition of the soil and increasing shoot growth (Aliyeh et al., 2002).

Also, amino acids could directly or indirectly improve the physiological activities of the plant and regulate growth and development through their influence on the biosynthesis of gibberllins (Walter and Nawacke, 1978) and may also play an important role in plant metabolism and protein assimilation which is necessary for cell formation (Sadak, 2015).

Active dry yeast contains cytokinines and vitamin B which increases the vegetative growth (Ezz El-Din and Hendawy, 2010).

The decrease in all parameters with increasing seawater percent from 10 to $20 \%$ combined with organic or bio stimulants may be attributed to that seawater stress has exerted the strongest effect in alleviating the harmful effect of seawater salinity (Abd el Kafie et al., 2010) on Tuberose.

\section{Root growth}

Salt stress may have a negative effect on roots growth. Kumar et al. (1988) observed a decrease in root length with the progressive increase in salt stress. Proline might counteract the negative effects of high salinity on carbohydrates and nitrogen metabolism which promote the whole plant growth (Lobartini et al., 1997).

\section{Biochemical composition}

The significant increase in leaves total chlorophyll by using humic acid followed by amino acids and then active dry yeast compared to control may be due to the role of humic acid in providing the plants with various nutrients necessary for synthesis of active constituents in the plant organs. This may be due to that application of $\mathrm{NaCl}$ significantly decreased chlorophyll contents in plant tissues (Oyetunji and Francis, 2004). These results are in accordance with those of (El sayed and Youssef, 2013) on Jasminum sambac. Likewise, spraying cotton plants with amino acid tended to increase proline in the leaves (Gebaly et al., 2013).

\section{Chemical composition}

\section{Nitrogen and magnesium}

High level of water salinity may reduce plant absorption of some important elements. The lowest $\mathrm{N} \%$ and $\mathrm{Mg} \%$ resulted from plants irrigated with $20 \%$ diluted seawater (Abdel-Fatah et al., 2008) on Tifway and (Caparros et al., 2017) on Aloe vera, L. Amino acids are the fundamental ingredients in the process of protein synthesis because of their nitrogen content (Kamar and Omar, 1987). Applying humic acid caused a limitation in the absorption of both $\mathrm{Na}$ and $\mathrm{Cl}$ elements (Khaled and Fawzy, 2011) on Nigella sativa, L.

\section{Sodium and chloride percentage}

Plants accumulate $\mathrm{Cl}$ ions in leaves which is more toxic in leaf tissues, plants make root production to remove excess ions and delay ion accumulation in tissues (Tozlu and Guy, 2000) on Poncirus trifoliata and (El-Mahrouk et al., 2008) on Conocarpus erectus L. 
Humic acid and amino acids significantly decreased $\mathrm{Na}$ and $\mathrm{Cl} \%$ in the leaves followed by active dry yeast (Abdel- Fatah, 2008) on Tifway turf.

\section{Conclusion}

It is recommended to irrigate Ruellia brittoniana plants with 5\% diluted seawater combined with organic or bio stimulants (humic acid $80 \%$ concentration $5 \mathrm{ml} / \mathrm{L}$, amino acids $26.18 \%$ concentrated free amino acids $1 \mathrm{~g} / \mathrm{L}$ or active dry yeast $5 \mathrm{~g} / \mathrm{L}$ ) as foliar spray on plant leaves fortnightly (20 spray/ season) to obtain the best growth and flowering characters.

\section{REFERENCES}

[1] A.O.A.C. (1970): Official Methods of Analysis. 10 ${ }^{\text {th }}$ Ed. - Association of Official Agriculture Chemists, Washington, DC.

[2] Abdel-Fatah, G. H., Boshra, A. E., Shahin, S. M. (2008): The role of humic acid in reducing the harmful effect of irrigation with saline water on Tifway turf. - J. Biol. Chem. Environ. Sci. 3(1): 75-89.

[3] Abourayya, M. S., Nabila, E. K., El-Sheikh, M. H. (2013): Effect of irrigation with saline water on fibrous root growth of Manzanillo and Picual olive cultivars. - Austral. J. of Basic and Appl. Sci. 7(1): 457-461.

[4] Ali, E. F., Hassan, F. A. S. (2013): Impact of foliar application of commercial amino acids nutrition on the growth and flowering of Tagetes erecta, L. plant. - J. of Appl. Sci. Res. 9(1): 652-657.

[5] Amer, S. S. A. (2004): Growth green pods yield and seeds yield of common bean (Phaseolus vulgaris L.) as affected by active dry yeast, salicylic acid and their interaction. - J. Agric. Sci., Mansoura Univ. 29(3): 1407-1422).

[6] Atiyeh, R. M., Lee, S., Edwards, C. A., Arancon, N. Q., Metzger, D. (2002): The influence of humic acids derived from earth worm-processed organic wastes on plant growth. - Bioresource Technol. 84: 7-14.

[7] Baters, L. S., Waldern, R. P., Teare, I. D. (1973): Rapid determination of free proline under water stress studies. - Plant and Soil 39: 205-207.

[8] Caparros, P. G., Lianderal, A., Lao, M. T. (2017): Effects of salinity on growth, water-use efficiency and nutrient leaching of three containerized ornamental. - Communication in Soil Sci. and Plant Analysis 48: 1221-1230.

[9] Carter, C. T., Grieve, C. M., Possmj, A., Suarez, D. L. (2005): Production and ion uptake of Celosia argentea with saline waste waters. - Sci. Hort. 106: 387-394.

[10] Chartzoulakis, K., Loupassaki, M., Ertaki, M., Androuakis, I. (2002): Effect of Nacl salinity on growth, ion content and $\mathrm{Co}_{2}$ assimilation rate of six olive cultivars. - Sci. Hort. 96: 235-247.

[11] El-Mahrouk, M. E., El-Nady, M. F., Hegazi, M. A. (2008): Effect of diluted seawater irrigation and exogenous prolline treatments on growth, chemical composition of Conocarpus erectus. - J. Agric. Res. Kafrelsheikh Univ. 36(4): 420-446.

[12] El-Sayed, B. A., Youssef, H. M. A. (2013): Effect of some mutagenic and humic acid treatments on vegetative growth and chemical composition of Jasinum sambac Var. Double Plants. - J. Biol. Chem. Environ. Sci. 8(1): 1-14.

[13] Ezz El-Din, A. A., Hendawy, S. F. (2010): Effect of dry yeast and tea compost on growth and oil content of Borago officinalis plant. - Res. J. of Agric. and Biol. Sci. 6(4): 424430. 
[14] Gebaly, S. F., Ahmed, M. M., Namich, A. A. M. (2013): Effect of spraying some organic, amino acids and potassium citrate on alleviation of drought stress in cotton plant. $-\mathbf{J}$. Plant Production, Mansoura Univ. 4(9): 1369-1381.

[15] Gilman, E. F. (1999): Ruellia brittoniana (Mexican bluebell). - Environ. Hort. Dept., UF/Ifas Extention, Gainesville, FL.

[16] Glenn, E. P., Brown, J. J., O’leary, J. W. (1998): Irrigating crops with seawater. Scientific Amer. 279: 56-61.

[17] Jackson, M. L. (1973): Soil Chemical Analysis. - Prentice-Hall of India Private Ltd. New Delhi.

[18] Kamar, M. E., Omar, A. (1987): Effect of nitrogenus levels and sprying with aminal-forte (amino acids salvation) on yield of cucumber and potatoes. - J. Agric. Sci. Mansoura Univ. 12(4): 900-907.

[19] Khaled, H., Fawzy, H. A. (2011): Effect of different levels of humic acids on the nutrient content, plant growth and soil properties under conditions of salinity. - Soil and Water Res. 6(1): 21-29.

[20] Kumar, A. B., Bahadur, B., Sharma, B. K. (1988): Effects of salinity on germination, seedling growth and some quantitative characters of Cyamoposis tetragonoloba, L. Taub. - New Botanist 15(1): 23-27.

[21] Lobartini, J. C., Oriole, G. A., Tan, K. H. (1997): Characterstics of soil humic acid fractions separated by ultrafilteration. - Commun. Soil Sci. Plant. 28: 787-796.

[22] Manoly, N. D., Nasr, A. A. (2008): Response of Dahlia pinnata plants to biofertilizer types. - Egypt. J. Exp. Biol. (Bot.) 4: 87-91.

[23] Mezanur Rahman, M. D., Mostofa, M. G., Abiar Rahman, M., Robyul Islam, M., Keya, S. S., Das, A. K., Giashuddin Miah, M. D., Robiul Kawser, A. Q. M., Ahsan, S. M., Hashem, A., Tabassum, B., Abd_Allah, E. F., Tran, L. P. (2019): Acetic cid: a costefective agent for mitigation of seawater-induced salt toxicity in mung bean. - Scientific Reports 9: 15186.

[24] Miyamoto, S., Glenn, E. P., Olsen, M. W. (1996): Growth, water use and salt uptake of four halophytes irrigated with highly saline water. - J Arid Environ. 32: 141-159.

[25] MSTAT Development Team (1989): Mstat User's Guide: A Microcomputer Program for the Design Management and Analysis Research Experiments. - Michigan State Univ. East Lansing, USA.

[26] Oyetunji, O. J., Francis, I. (2004): Effect of salt stress on growth, proline, glycine betaine and photosynthetic pigment concentrations on cowpea plant. - Nature and Science 2(12).

[27] Parida, A. K., Das, A. B. (2005): Salt tolerance and salinity effects on plants. A review. Ecotoxicology and Environmental Safety 60(3): 324-349.

[28] Richard, S., Hamilton, C. W. (1997): Predicting invasions of woody plants introduced into North America. - Conservation Biology 11: 193-203.

[29] Sadak, M. S., Abdelhamid, M. T., Schmidhalter, U. (2015): Effect of foliar application of amino acids on plant yield and some physiological parameters in bean plants irrigated with seawater. - Acta Biol. Colomb. 20(1): 141-152.

[30] Sairam, R. K., Tyagi, A. (2004): Physiology and molecular biology of salinity stress tolerance in plants. - Curr. Sci. 86: 407-421.

[31] Singh, K. N., Chatrath, R. (2001): Salinity Tolerance. - In: Reynolds, M. P., OrtizMonasterio, J. I., Mcnab, A. (eds.) Application of Physiology in Wheat Breeding. CIMMYT, D. F. Mexico, pp. 1-110.

[32] Srivastava, R., Govil, M., Chow, K. K. (2007): Influence of biofertilizers on growth and flowering in Gladiolus cv. American Beauty. - Acta Hort. 742: 183-188.

[33] Tozlu, I. G. M., Guy, C. L. (2000): Effects of increasing $\mathrm{NaCl}$ concentration on stem elongation, dry mass production and macro and micro-nutrients accumulation in Poncirus prifoliate. - Aust. J. Plant Physiol. 27: 35-42.

[34] Walter, G. R., Nawacki, E. (1978): Alkaloid Biology and Metabolism in Plants. - Planum Press, New York. 
[35] Winston, G. W. (1990): Physicochemical Basis for Free Radical Formation in Cells: Production and Defenses. - In: Alscher R. G., Cumming J. R. (eds.) Stress Responses in Plants: Adaptation and Acclimation Mechanisms. Wiley-Liss Inc., New-York, pp. 57-86.

[36] Zadeh, I. Y., Mirzakhani, A. (2012): Study effect of thyme Oil., salicylic acid, Aloe vera gel and some chemical substances on increasing vase life of cut Dianthus caryophyllus. Inter. J. Agron. Plant Production 3: 666-674. 